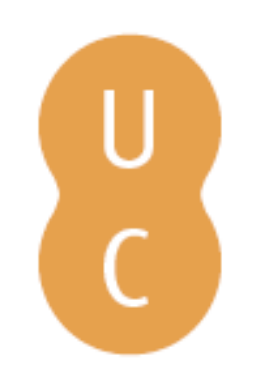

\title{
pompalina
}

\section{The tyrannos as a sophos in the Septem Sapientium Convivium}

\author{
Autor(es): Leão, Delfim \\ Publicado por: Imprensa da Universidade de Coimbra; Centro de Estudos Clássicos e
}

URL

persistente: URI:http://hdl.handle.net/10316.2/32042

DOI: $\quad$ DOI:http://dx.doi.org/10.14195/978-989-8281-17-3_47

Accessed : $\quad$ 26-Apr-2023 15:09:52

A navegação consulta e descarregamento dos títulos inseridos nas Bibliotecas Digitais UC Digitalis, UC Pombalina e UC Impactum, pressupõem a aceitação plena e sem reservas dos Termos e Condições de Uso destas Bibliotecas Digitais, disponíveis em https://digitalis.uc.pt/pt-pt/termos.

Conforme exposto nos referidos Termos e Condições de Uso, o descarregamento de títulos de acesso restrito requer uma licença válida de autorização devendo o utilizador aceder ao(s) documento(s) a partir de um endereço de IP da instituição detentora da supramencionada licença.

Ao utilizador é apenas permitido o descarregamento para uso pessoal, pelo que o emprego do(s) título(s) descarregado(s) para outro fim, designadamente comercial, carece de autorização do respetivo autor ou editor da obra.

Na medida em que todas as obras da UC Digitalis se encontram protegidas pelo Código do Direito de Autor e Direitos Conexos e demais legislação aplicável, toda a cópia, parcial ou total, deste documento, nos casos em que é legalmente admitida, deverá conter ou fazer-se acompanhar por este aviso.

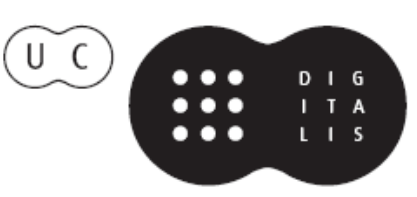




\section{Symposion and Philanthropia in Plutarch}

\section{José Ribeiro Ferreira, Delfim Leão Manuel Troster e Paula Barata Dias (eds.)}

IMPRENSA DA UNIVERSIDADE DE COIMBRA 


\title{
THE TYRANNOS AS A SOPHOS IN THE SEPTEM SAPIENTIUM CONVIVIUM
}

\author{
Delfim Leão \\ University of Coimbra
}

\begin{abstract}
The group of the Seven Sages in the Septem Sapientium Convivium includes a number of figures whose presence is problematic due to their association with autocratic power. Although the invitation to the meeting was sent out by the tyrant Periander, he is nevertheless eliminated from the central core of the Sages. This decision may be justified, in the first place, by the fact that he is a tyrant and that there is a deep animosity towards this form of government in the Convivium. Nevertheless, Periander was expected to fulfil a more important function in his capacity as host, but, contrary to this scenario, his presence begins to recede, especially once the eulogy of the democratic system starts, to the point that the honour of closing the banquet falls to Solon. Even so, Pittacus has ruled over the destinies of Mytilene as an aesymnetes and continues to figure among the sophoi, and the same can be said of Cleoboulus, the autocrat of Lindos. Taking these factors into account, I propose to discuss in this paper the reason why Pittacus and Cleoboulus were able to remain as sophoi, while Periander ended up being relegated to a secondary place.
\end{abstract}

In my earlier work, I argued that the Septem Sapientium Convivium represents, in a certain way, a kind of cosmopolis of different sorts of wisdom ${ }^{1}$. Among the sophoi, the dominant profile corresponds, as should be expected, to the masculine, aristocratic and Greek sensibility, as shown in the characters of Solon, Thales, Bias, Cleoboulus, Pittacus and Chilon. The seventh figure of the gallery is occupied by the Scythian Anacharsis, a personality that a long-lasting tradition ${ }^{2}$ used to consider under the double perspective either of a sort of martyr of Greek culture or of a "bon sauvage" still uncorrupted by the vices of civilization and, because of that, apt to deprecate those same vices without being subject to the compromises of social convenience. Besides that, Anacharsis also adds a note of eccentricity to the group of sapientes, as he too ends up representing the nomadic oddness of the northern barbarians. ${ }^{3}$

The group of the sophoi as a whole is not, nevertheless, the object of the approach I intend to present, which rather deals with the image of the tyrannos as a sophos in the banquet of the Seven Wise Men. Solon, Thales, Bias and Chilon are usually present in the stable nucleus of the Seven but do not correspond to the tyrannos/sophos profile. Accordingly, their example is

${ }^{1}$ The results of these several studies were gathered in a single global analysis, published in D. F. LEÃo, 2006. See also D. F. LEÃo, 2008. I would like to express my gratitude to Manuel Tröster, who read an earlier version of this paper and improved a lot on the English.

${ }^{2}$ Present already in Herodotus, 4.76-77.

${ }^{3}$ To this relatively exotic ambience contributes as well Neiloxenos, Amasis' envoy to the court of Periander, who can be considered, to a certain point, an example of Egyptian sophistication, although he does not belong to the restricted circle of the Seven Wise Men. I shall later return to him and to other secondary figures like the young Cleobouline (or Eumetis), who, along with Aesop, represents a more intuitive knowledge. 
adduced only to strengthen the contrast with other personalities present in the Convivium: Pittacus and Cleoboulus, in their role of sapientes, and Periander in the quality of the meeting's host. What these three figures have in common is the fact that they all represent autocratic regimes. There are, nevertheless, important differences of detail that might help to understand the dissimilar way in which Plutarch characterized them. Besides, this happens not only in the Convivium but is also detectable elsewhere in his oeuvre, for instance in the De E apud Delphos (385d-e), where the author reduces the number of sapientes to only five (Chilon, Thales, Solon, Bias and Pittacus), expressly excluding the tyrants Cleoboulus and Periander. This clearly shows that Plutarch is somehow reluctant to include tyrannoi among the group of sophoi. Such a perspective is hardly surprising, because even in earlier representations of tyranny (dating especially back to the fifth and fourth centuries) the concept of autocratic rule in general was closely connected with the idea of illegitimacy, the use of mercenary troops, personal abuse and contempt for the laws of the city ${ }^{4}$. Nevertheless, it should also be taken into account, as I shall argue, that a positive tradition related with the tyrants is also found in the sources, probably owing its formation to an oral tradition that goes back to the time when some of these more ancient figures lived (the sixth century). It is very important to be aware of this in order to understand and solve the apparent contradiction of Plutarch's portrayal of these characters in the Septem Sapientium Convivium, where a certain tension can be detected in their treatment, as well as a positive appraisal. In discussing the question, I shall start by evoking some fundamental traits of each personality in the literary tradition. However, this should not be seen as a mere exercise of Quellenforschung, but as a preliminary step towards understanding Plutarch's options when he decided to describe a symposion with the Seven Sages.

\section{Pittacus of Mytilene}

Pittacus was an aristocrat of Lesbos who involved himself directly, as did the poet Alcaeus, in the political struggles that affected the island during the VII and VI centuries. In an initial phase of his active life, he joined Alcaeus and Antimenides (the poet's brother) in order to depose the tyrant Melanchrus, whose government would be substituted by that of Myrsilus, with whom Pittacus then aligned himself, to the bitter resentment of his former allies, who had to go into exile. Myrsilus' death was celebrated in Alcaeus' verses with enormous elation ${ }^{5}$, and it was in a context of great political and social instability that Pittacus rose to power, at the turn of the VI century (around 590/89), ruling over the destinies of Mytilene over ten years. Although they had worked together in the past, Pittacus' government is repeatedly criticized by Alcaeus, who considers his rise to power an act of madness by the Mytileneans

\footnotetext{
${ }^{4}$ See C. Mossé, 2006, 189, in discussing Plato and Plutarch on the Sicilian tyrants.

${ }^{5}$ Cf. frg. 332 Voigt.
} 
and a consecration of tyranny ${ }^{6}$. This opposition from exile represents a clear sign that Pittacus was progressively moving away from the aristocrats who started by giving him their support, and that this evolution in behaviour had, as counterpart, the effect of drawing him closer to the popular classes. In this respect, Pittacus' political career is not different from that of other autocratic leaders. However, there are two aspects that turn his experience of government into something strikingly singular: first, Pittacus rose to power not by force, but in the quality of a sovereign elected by the people (aisymnetes); second, the sources sustain that, once he managed to calm the atmosphere of civil dissension, he abandoned the government of his own free will and died around ten years later (possibly c. 570).

These are precisely the aspects that deserve a deeper analysis now, because they will provide, with great probability, the explanation for the fact that, although being a tyrannos, Pittacus managed to be considered one of the Seven Wise Men and retained that same position in Plutarch's Convivium. It is therefore worthwhile to ponder more carefully the passage where Aristotle mentions the way Pittacus rose to power (Pol. 3.1285a29-1285b3):

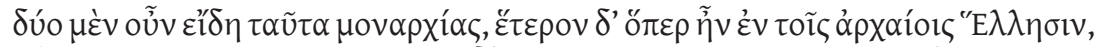

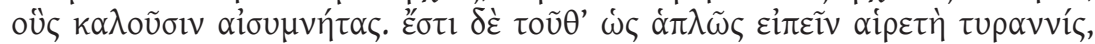

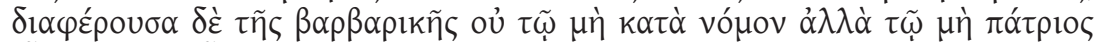

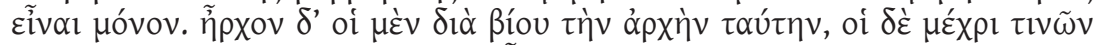

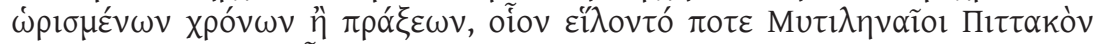

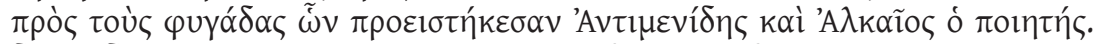

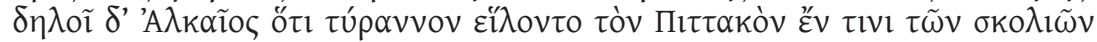

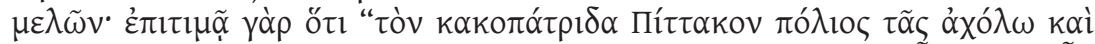

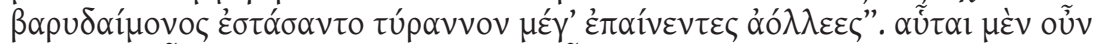

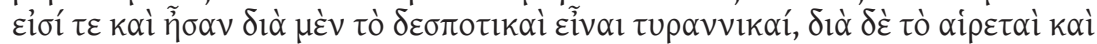

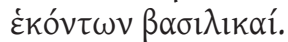

Although Alcaeus' testimony, referred to in this passage, shows that at least

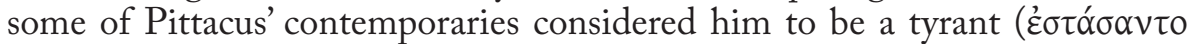

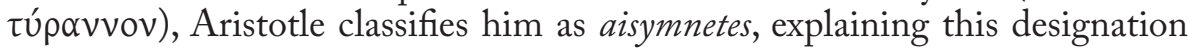
with the fact that he was elected autocrat by the people of Mytilene Accordingly, Aristotle attributes to aisymneteia a position between tyranny and hereditary monarchy, taking more into account the way Pittacus rose to power than the manner in which he may have ruled. However, later authors like Strabo (13.2.3) and Diogenes Laertius (1.75) record that Pittacus abandoned tyranny of his own will, and it is perhaps not illegitimate to conclude from these testimonies that he exerted autocratic power in a positive manner and mainly with the goal of calming the atmosphere of civil dissension that may have justified his appointment as tyrant ${ }^{7}$.

${ }^{6}$ Frgs. 75 and 348 Voigt (cf. infra commentary to Pol. 3.1285a29-1285b3). In other poems (frgs. 69, 70 and 72 Voigt), the poet continues to attack Pittacus in other ways, citing, for example, his physical looks, his opportunism and tendency towards violent behaviour.

7 The testimony of Diodorus (9.11.1) is particularly elucidative by the way it synthesizes 
Although the question is controversial, it is not improbable that the term aisymnetes was used in Pittacus' time to describe his government and that Aristotle may therefore have adopted from Pittacus' ruling experience the same expression to refer to this political category, an hypothesis that finds support in the fact that Pittacus' case is precisely the sole example of an aisymnetes that Aristotle provides 8 . This term, however, is used already by Homer to define someone engaged in activities appropriate for a 'judge' or informal 'evaluator' . The confluence of these several aspects must have contributed to create a quite favourable image of Pittacus, to the point of him being considered one of the Seven Wise Men.

Up to a certain point, it is also appealing to compare Pittacus' role as aisymnetes with the position of diallaktes ('arbiter') that Solon held in Athens ${ }^{10}$. Both seem to have enjoyed strong support from the people who had put the government of the city into their hands, in the expectation that they might bring to an end the ambience of enormous instability felt by then in Mytilene and in Athens. Both were equally well succeeded in these functions, notwithstanding the opposition they also met, and both also chose not to remain in power as tyrants. Moreover, both of them acted as lawgivers, although at this level Solon's activity is much more notorious and influential - a clear sign of this is given by the fact that Aristotle says that Pittacus was responsible for the creation

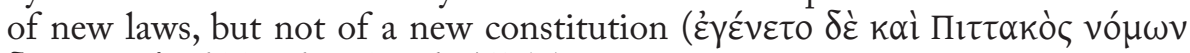

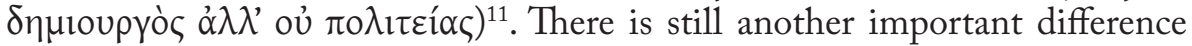
to add in considering the two statesmen: although Pittacus was a tyrant aisymnetes, this does not necessarily imply that such a political position was regular; Solon, on the contrary, had on his side the supplementary legitimacy of occupying a legal office (the archonship), reinforced by the concession of exceptional powers.

At any rate, and even taking into account these limitations, Pittacus' situation was sufficiently special to allow him to keep deserving the post of

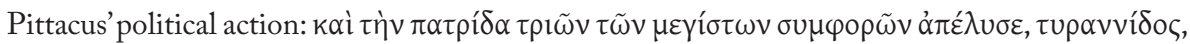

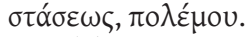

8 The fragment of Alcaeus quoted by Aristotle shows that the word tyrannos could have a pejorative connotation as early as the turn of the VII to the VI century, although in this particular case the negative overtone should also be understood as an expression of the poet's own animosity towards the former political ally. In fact, in the Septem Sapientium Convivium (157d-e), Plutarch records a popular song from Lesbos which mentions Pittacus as a basileus; if the testimony is genuine, it will contribute to show that, before the time of Thucydides, the concepts of tyrannos and basileus were not necessarily opposites. On this matter, see the pertinent observations of V. PAR Ker, 1998, pp. 156-7 and 170-1, n. 130.

${ }^{9}$ In the sense that the aisymnetes was not a regular official. Cf. Il. 24.347; Od. 8.258. See also J. F. McGlew, 1993, pp. 79-81; K.-J. HölKeskamp, 1999, pp. 219-26.

${ }^{10}$ Cf. [Aristotle], Ath. 5.2; Plutarch, Sol. 14.3.

${ }^{11}$ Pol. 2.1274b18. This commentary is made when Aristotle is about to mention the bestknown law of Pittacus: the one that defines harsher penalties for crimes committed under the influence of wine. This tradition also left traces in the Septem Sapientium Convivium (155f). On the remnants of other pieces of legislation implemented by Pittacus, see K.-J. HöLKeskamp, 1999, pp. 221-3. 
sapiens in a period during which animosity towards autocratic rulers was well established, even within the tradition of the Seven Wise Men. On the other hand, the ethical and political resemblances between him and Solon must also have helped to confirm the legitimacy of his presence in the symposion, because the Athenian legislator (together with Thales) played an undisputed central role both in the Seven Sages tradition and in Plutarch's Convivium.

\section{Cleoboulus of Lindos}

Cleoboulus, son of Evagoras, was tyrant of Lindos during around forty years, until the middle of the VI century. Even so, the information given by the sources about this figure is much less expressive than in the case of Pittacus and, because of that, maybe the justification for his presence in the Septem Sapientium Convivium should be sought not in his own credits but rather in a kind of homage that Plutarch would like to pay to Cleobouline/Eumetis. The young girl is presented as the daughter of the autocrat Cleoboulus, but one of the first objections to ponder in this context has to do precisely with the historical existence of Cleobouline. In fact, we have the record of a comedy from Cratinus called Kleoboulinai, and because of this it has already been argued that her name may simply be a personification of the riddles invented by Cleoboulus ${ }^{12}$. Elsewhere Plutarch states (De Pythiae oraculis, 401b) that her real name was Eumetis, although it was superseded by the nickname Cleobuline, given after her father. Anyway, more significant than this detail is the fact that Eumetis is a name that speaks for itself: it means 'prudent' or 'wise', and this is in accord with the characterization of the young girl in the Convivium and with the positive effect that she exerts upon her father - which is the aspect that is most relevant to the subsequent analysis.

In fact, the presence of Cleoboulus is quite discreet throughout the Septem Sapientium Convivium. Bias discusses some ideas apart with him before giving his response to the enigmatic questions advanced in Amasis' missive (151c). However, this procedure may be justified simply by the fact that Cleoboulus is reclined close to Bias, thereby not implying any special deference towards the tyrant of Lindos. Cleoboulus is also responsible for some short observations on political regimes and on the government of the house, suggesting by these interventions to have a moderate nature. His major contribution has to do with the way he explores the concept of $\mu \varepsilon$ r $\rho \circ$ v (157a-c), but even this may be understood as an explanatory development of the sentence $\mu \varepsilon^{\prime} \tau \rho \mathrm{v}$ óp which was traditionally attributed to $\mathrm{him}^{13}$. This second-rate position of

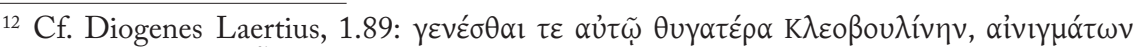

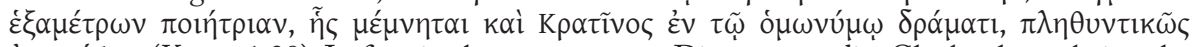

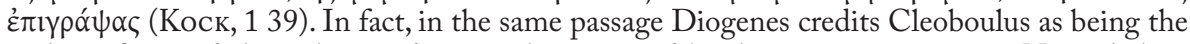
author of around three thousand verses characterized by their enigmatic nature. Nevertheless, Diogenes seems to believe in the historical existence of Cleobouline, a perspective which is in fact preferable. On this see D. Fehling, 1985, pp. 48-9; A. Bernabé Pajares \& H. Rodríguez Somolinos, 1994, pp. 128-9.

${ }^{13}$ Cf. Diogenes Laertius, 1.93.5. 
Cleoboulus is again stressed by Plutarch in the De E apud Delphos (385d-e), a passage already commented on in the introduction, where he expressly eliminates the tyrant of Lindos from the core of Sages. Accordingly, it would have been easy for Plutarch to choose a character different from that of Cleoboulus, among the many other candidates recorded by the tradition of the Seven Wise Men ${ }^{14}$. Consequently, the justification for the presence of the tyrant Cleoboulus within the circle of the sophoi should perhaps be sought not so much in the inherent qualities of the autocrat (as happened with Pittacus) but in the opportunity to make Cleobouline appear in the convivial space ${ }^{15}$.

In fact, although the young girl does not voice a single word, it is particularly impressive to see the way she is presented for the first time in the Septem Sapientium Convivium in the act of combing the dishevelled hair of Anacharsis (148d-e). The symbolic importance of this scene is underlined during the conversation between Neiloxenos and Thales when it is said that both the Greek girl and the Scythian sophos derived benefits from that mutual proximity. Neiloxenos also pays her a compliment by recognizing that her riddles were renowned as far as Egypt. This is a very interesting statement because, apart from the obvious flattering remark, it may also provide an historical hint at the way personalities and events connected with the Seven Sages spread throughout the Hellenized world. ${ }^{16}$ Particularly significant is also the comment made by Thales when he emphatically mentions the natural good character of Eumetis to the foreigner of Naucratis and at the same time states the positive effect that she exerts on her father (148d):

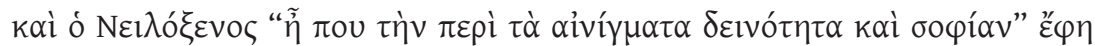

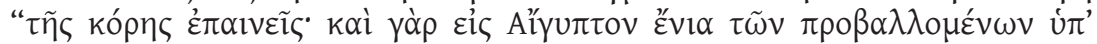

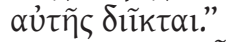

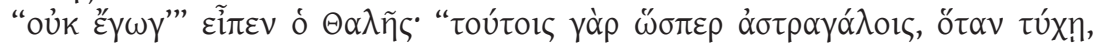

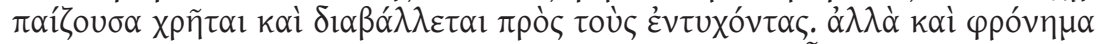

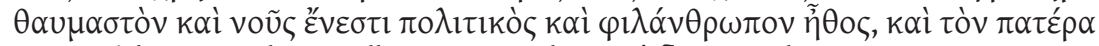

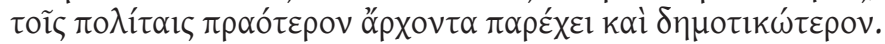

According to him, the natural qualities of Cleobouline - where intelligence, political sensibility and a generous character are particularly

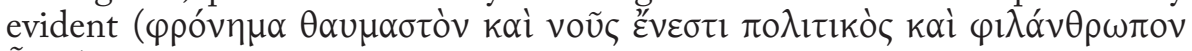
$\tilde{\eta} \theta 0 \varsigma)$ - project over her father and help to make his government become

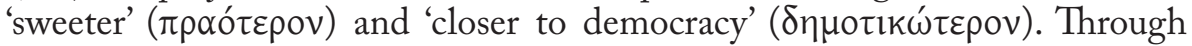
Eumetis, Plutarch manages to attenuate the negative traits of Cleoboulus and

${ }^{14}$ See the elucidative testimony of Diogenes Laertius (1.41-42) on the number of personalities that could play the role of sophos.

15 Thus contributing to innovate within the Greek tradition in what concerns the presence of 'serious' women in the banquet, which was an ambience clearly marked by masculine Weltanschauung. For more on this, see D. F. LEÃo, 2008, pp. 486-7.

${ }^{16}$ A. Busine, 2002, pp. 65-71, too, calls attention to this issue, when analysing the work of Demetrius of Phalerum and Callimachus of Cyrene in Alexandria. However, the author does not discuss this particular case of Cleobouline. 
dilutes the fact that he is tyrant of Lindos, thus making it easier to accept his inclusion in the restricted group of the Seven Wise Men. To put it in a nutshell: Plutarch allows Cleoboulus to be considered one of the Sages this time in order to have the opportunity of presenting in the Convivium the young Eumetis, in whom one can detect special traits of feminine sensibility and of the positive effect they produce within the masculine space of the symposion.

\section{Periander of Corinth}

In the analysis of Pittacus' and Cleoboulus' characters, I have not adduced an argument that could have carried some weight in Plutarch's choices: the fact that his core of sophoi is very similar to the list presented in Plato's Protagoras (343a). In fact, although Plato has Anacharsis replaced by Myson, he also includes the names of Pittacus and Cleoboulus, leaving Periander equally aside $^{17}$. This mistrust towards tyranny is found in other parts of Plato's work, the best-known passage being the one in the Republic (335e-336a) where, to the wisdom of figures like Simonides, Bias and Pittacus, he opposes the image of personalities inebriated by wealth, in a group headed precisely by Periander, but where Perdiccas, Xerxes and Ismenias of Thebes are also present. One of the important things about this passage of the Protagoras is that it provides the first complete list of the Seven Wise Men. A clear sign that Plato was innovating in supplying the full sylloge in writing is given by the fact that the philosopher presents «l'intégralité des sept noms et leurs ethniques respectifs» ${ }^{18}$. If this was not the case, it would be more natural to refer to the

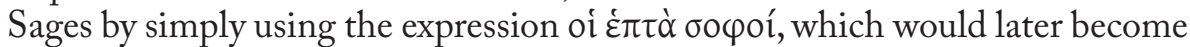
the usual designation ${ }^{19}$. Solon is the only sophos of whom the ethnonym is not given; rather he is designated by Socrates as $\Sigma o ́ \lambda \omega v$ ó $\eta \dot{\mu} \varepsilon \dot{\tau \varepsilon \rho o \zeta . ~ T h i s ~ s u g g e s t s ~}$ that, from the very beginning, Solon was a polarizing personality among the Sages and that Athenian influence played an important role in establishing their political and ethical idiosyncrasy. ${ }^{20}$ This is still clearly visible in Plutarch's Convivium, as shown by the importance attributed to the old legislator and to the democratic regime in terms of political discussion.

The elimination of Periander from the core of Sages is thus justified, in the first place, by the fact that he was a tyrant and that there is a deep animosity towards this form of government in the Convivium, inherited from

${ }^{17}$ Possibly following Ephorus; by contrast, Demetrius of Phalerum admitted the presence of Periander. See the aforementioned testimony of Diogenes Laertius, 1.41-42.

${ }^{18}$ A. Busine, 2002, pp. 33-4, who also calls attention to the fact that Plato presented already in the Hippias Major (281c) what could be considered a "proto-list" of the sapientes (pp. 31-2).

${ }^{19}$ This does not imply, of course, that Plato was himself creating the legend of the Seven Wise Men, because, as said before, it should already have been present in the oral tradition.

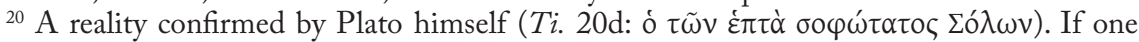
takes into consideration that this dialogue was written after the Protagoras, then it becomes significant that, this time, Plato felt that it was no longer necessary to provide the whole sylloge. On this see A. Busine, 2002, p. 36. 
Plato and echoed equally by Plutarch at several points of his work ${ }^{21}$. Periander admittedly fulfils an important function in his capacity as host, although his presence starts to vanish especially when the guests begin the eulogy of the democratic regime, to the extent that the honour of closing the banquet falls to Solon and not to the host $(164 \mathrm{c}-\mathrm{d})$. In order to reach a better understanding of the more specific reasons that may lie behind this treatment, it will be useful to recall some further information concerning the life of the tyrant of Corinth.

Periander, son of Cypselus, was in power for about forty years (c. 627 to $587 \mathrm{BC}$ ). Under his government, Corinth reached a notable development at the economic, military and cultural levels, as can be seen by the foundation of several colonies, by important military campaigns, and by the tyrant's capacity to attract to his court poets and other artists ${ }^{22}$. This image of a successful ruler and protector of the arts, common in fact to several other tyrants of ancient Greece, should have been the reason why he was sometimes placed among the group of sapientes ${ }^{23}$. On the other hand, Periander also has the image of a person given to excesses, a tradition that Plutarch could not afford to ignore, as shown by the allusions made to them in the Convivium. This is what happens, for example, with the practice of incest with his mother, a hideous crime that led her to commit suicide ${ }^{24}$; the future uxoricide of Melissa ${ }^{25}$; or even a crime as repulsive as the practice of necrophilia with his wife's corpse ${ }^{26}$. This latter transgression was reinforced by other forms of equally shocking intemperance: still according to the same passage in Herodotus, Periander ordered the women of Corinth to gather in the temple of Hera, with the goal of having them stripped and all their clothes burned in order to appease the spirit of Melissa - significantly not to obtain her pardon, but to feed his continuous thirst for wealth. Although in the Septem Sapientium Convivium there is no tension between the two (Melissa does not even speak), Plutarch's readers were already aware of Periander's subsequent excesses and therefore knew what was going to happen to him ${ }^{27}$. Nevertheless, it is worth noting that even in Herodotus there are also a few positive hints concerning Periander,

${ }^{21}$ Even with notable animosity. Cf. Dio 9.3-8; Arat. 26.1-5.

${ }^{22}$ Like Chersias of Orchomenus, known precisely from his participation in the Septem Sapientium Convivium.

${ }^{23}$ Note that, according to Diogenes Laertius (1.122), a few authors also considered Peisistratus, tyrant of Athens, one of the sophoi.

${ }^{24}$ Cf. Septem Sapientium Convivium, 146d. The incestuous relation of Periander with his mother is attributed by Diogenes Laertius (1.96) to Aristippus. Parthenius (Erotika Pathemata 17) presents a more romanticising version of the account, which bears some similarities to Apuleius' Cupid and Psyche.

${ }^{25}$ Cf. Herodotus, 3.50; Diogenes Laertius, 1.94.

${ }^{26}$ Herodotus, 5.92. . 1-4.

${ }^{27}$ Something similar occurs, for example, with the indication that Aesop participated in the banquet as Croesus' envoy after the latter had sent him to the court of Periander and to the oracle of Delphi (150a). In a certain way, this detail throws a shadow of discomfort over his participation, since, according to the legend, Aesop would suffer a violent death in Delphi for having disrespected the priests of the oracle and the inhabitants of the region by accusing them of simple parasitism. 
like the story of Arion and the dolphins (1.23-24), which is recovered and developed in Plutarch's Convivium (160e-162b). And even episodes like banishing or putting to death the most influential citizens, and burning the clothes of the Corinthian women, were sometimes interpreted as reflecting a positive motivation: to promote social balance and implement sumptuary legislation ${ }^{28}$. In fact, in the Convivium Plutarch does not forget to mention the detail that the tyrant told his wife to dress in a simple manner for the dinner with de Seven Wise Men (150d). This conflicting evidence suggests that there were two different traditions concerning Periander: one mainly hostile to the tyrant, which is widely detected in Herodotus, and another pervaded with more positive traits, possibly Corinthian in origin ${ }^{29}$.

If one takes all these aspects into consideration, it will become quite clear that, despite the fact that Periander played an important role as host of the Convivium, Plutarch had to put him at a level different from the one occupied by the Seven Wise Men. At any rate, the relationship with the sapientes helped Periander - who inherited the tyranny as if it was a disease $(147 \mathrm{c})$ - to exercise power in a more moderate fashion, at least in the initial phase of his government $^{30}$. Although Plutarch concedes him some deference along with the interventions he makes during the symposion, the tyrant of Corinth thus fails to exhibit the serenity characteristic of someone who is at peace with his conscience, certainly because of the excesses already perpetrated, which constitute a clear sign that he will continue to reveal in the future the same propensity to immoderation. As such, he keeps living in fear of the deity he knows he has offended (146d) and this leads him to anxiety and superstitious terror, visible at the moment a shepherd carries a new-born centaur to the gardens of the palace $(149 \mathrm{c}-\mathrm{e})$. Even if Thales' rationalism helps him to dispel, at least temporarily, the shadow of apprehension, it is a matter of fact that the qualms manifested by Diocles will find their confirmation in the time to come $^{31}$. Periander also tries to overcome, with apotropaic rituals directed to

${ }^{28}$ See J. B. Salmon, 1997, pp. 46-65. Aristotle (Pol. 5.1311a20-22; 5.1313a40) tells the story of 'lopping off the heads' (an advice that according to him was given by Periander and not by Thrasybulus, as sustained by Herodotus) in a context where he seeks to exemplify the excesses characteristic of tyranny. The episode is also recorded by Plutarch in the Septem Sapientium Convivium (147c-d). In another study, J. B. SALmon, 1984, p. 206 e n. 80, points out that, according to Diogenes Laertius (1.100) and Theodorus Metochites (p. 668 Müller), Periander was an aisymnetes, similar to Pittacus, but the scholar rightly considers neither of these testimonies to be trustworthy.

${ }^{29}$ See A. Busine, 2002, pp. 21-2, who also states (p. 73) that Ephorus was one of the authors responsible for partially rehabilitating Periander as politician.

${ }^{30}$ V. PAR KER, 1998, pp. 166-7, calls attention to the fact that, when considering the different ways of reaching tyranny, Aristotle does not discuss the case of those (Periander of Corinth, Pindarus of Ephesus, Hippias of Athens and Polycrates of Samos) who inherited power from their fathers, a factor that would make their political position closer, in a certain way, to the status of basileus.

${ }^{31}$ Diocles advised the tyrant to make purifications in order to appease the deity (Aphrodite) that once again manifested herself because of the incestuous relations of Periander with his mother. As remarked above, the tyrant will end up killing his wife and losing all his children 
Aphrodite and Poseidon (146d, 160d), the fear generated by the warnings he keeps receiving through dreams and oracles, but that will not be enough to dry up the seeds of disgrace that are still feeding from his acts and shall, sooner or later, fructify.

To conclude: Plutarch seems to have been sensitive to the position Periander held in the tradition of the Seven Wise Men and, because of that, he decided to characterize him as someone close to the sophoi, by giving him the role of host in the meeting of the sapientes, at an early stage of his government. Nevertheless, the author's reservations about tyranny (inherited from Plato) and the awareness of the fact that Periander carried along with him the image of deeply shocking excesses must have led Plutarch to the decision that the tyrant was not suitable to be part of the core of Sages, contrary to what happened with Pittacus and Cleoboulus, due to the reasons discussed above.

At any rate, the presence in the group of sophoi of several figures connected with autocratic regimes must represent a sign of the antiquity of this tradition. In fact, the animosity towards tyranny as such was certainly not present at the earlier stages of the legend ${ }^{32}$. The odious character of the term is mainly a consequence of the Thirty Tyrants' oppressive and violent behaviour when they ruled over Athens in 404. Plato already records this growing acrimony that was to be transmitted to later tradition and finds a clear expression in Plutarch's Convivium. However, two of these figures were able to fulfil enough conditions to keep being considered part of the group, either owing to personal merits (Pittacus) or due to the positive influence of a close relative (Cleoboulus). In Periander's case, however, the shadow of domestic excesses severely dimmed the light of his political, military and cultural achievements, to the extent that Plutarch was no longer able to recognize in him the entire dignity of a fully-fledged sophos.

\section{WORKS CITED}

Aalders, G. J. D., "Political thought in Plutarch's Convivium Septem Sapientium”, Mnemosyne, 30 (1977) 28-39.

Aubonnet, J., Aristote. Politique. Tome II. Livres III et IV, texte établi et traduit par, Paris, 1971, 2002 (rev. ed.).

Bernabé Pajares, A. \& Rodríguez Somolinos, H., Poetisas griegas, Madrid, 1994.

(both legitimate and illegitimate), to the point of being forced to leave the throne to his nephew, Psammetichus. Psammetichus would then take the name Cypselus II, meeting his death only three years after having reached power, thus putting an end to the dynasty of the Cypselids. Cf. Herodotus, 3.50-53.

${ }^{32}$ In the first occurrence of the term (frg. 19 WEST of Archilochus), tyranny is considered to be 'powerful' 'great' ( $\mu \varepsilon \gamma \alpha \dot{\alpha} \lambda \eta)$, and even in the second half of the $\mathrm{V}$ century the words tyrannos and tyrannis are still used with the meaning of 'king' 'sovereign' 'wealth' 'power', although the negative tones are also detectable already in an early phase (frg. 33 West of Solon). On this see V. PARKer, 1998. 
Busine, A., Les Sept Sages de la Grèce antique, Paris, 2002.

Fehling, D., Die sieben Weisen und die frühgriechische Chronologie. Eine traditionsgeschichtliche Studie, Bern, 1985.

Hölkesкamp, K.-J., Schiedsrichter, Gesetzgeber und Gesetzgebung im archaischen Griechenland, Stuttgart, 1999.

LEÃo, D. F., “A tradição dos Sete Sábios: o sapiens enquanto paradigma de uma identidade", in D. F. LeÃo et Al., Paideia e cidadania na Grécia antiga, Coimbra, 2006, pp. 35-78.

"Plutarch and the Character of the Sapiens", in A. G. Nixolaidis (ed.), The Unity of Plutarch's Works. Moralia Themes in the Lives, Features of the Lives in the Moralia, Berlin/New York, 2008, pp. 480-88.

McGlew, J. F., Tyranny and Political Culture in Ancient Greece, Ithaca, 1993.

Mossé, C., "Plutarch and the Sicilian tyrants", in S. Lewis (ed.), Ancient Tyranny, Edinburgh, 2006, pp. 188-196.

Parker, V., "Túpavvoc. The semantics of a political concept from Archilochus to Aristotle", Hermes, 126 (1998) 145-72.

Salmon, J. B., Wealthy Corinth. A History of the City to 338 B.C., Oxford, 1984.

"Lopping off the heads? Tyrants, politics and the polis", in L. G. Mitchell \& P. J. Rhodes (eds.), The Development of the Polis in Archaic Greece, London, 1997, pp. 60-73. 